\title{
Design and Implementation of Automatic Water Spraying System for Solar Photovoltaic Module
}

\author{
L. Ashok Kumar, ${ }^{1}$ V. Indragandhi, ${ }^{2}$ Yuvaraja Teekaraman $\mathbb{D}^{3},{ }^{3}$ Ramya Kuppusamy (D), \\ and Arun Radhakrishnan (iD ${ }^{5}$ \\ ${ }^{1}$ Department of Electrical and Electronics Engineering, PSG College of Technology, Coimbatore 641004, India \\ ${ }^{2}$ School of Electrical Engineering, Vellore Institute of Technology, Vellore 632014, India \\ ${ }^{3}$ Department of Electronic and Electrical Engineering, The University of Sheffield, Sheffield S1 3JD, UK \\ ${ }^{4}$ Department of Electrical and Electronics Engineering, Sri Sairam College of Engineering, Bangalore 562106, India \\ ${ }^{5}$ Department of Electrical \& Computer Engineering, Jimma Institute of Technology, Jimma University, Jimma, Ethiopia
}

Correspondence should be addressed to Yuvaraja Teekaraman; yuvarajastr@ieee.org and Arun Radhakrishnan; arun.radhakriahnan@ju.edu.et

Received 2 October 2021; Revised 13 November 2021; Accepted 27 December 2021; Published 17 January 2022

Academic Editor: Abu Zaharin Ahmad

Copyright (C 2022 L. Ashok Kumar et al. This is an open access article distributed under the Creative Commons Attribution License, which permits unrestricted use, distribution, and reproduction in any medium, provided the original work is properly cited.

Photovoltaic (PV) cell has a characteristic of decrease in power beyond a certain temperature. This decrease in power is due to a drop in the open circuit cell voltage. This decreases the efficiency of the PV cell. The objective of this research is to increase the efficiency of PV cells by reducing the PV cell temperature and reflection loss. The cell temperature and reflection loss can be reduced by spraying water over the PV cells. On spraying water over the USP36, 24V PV module, the power is found to be increased. The test result shows a $1 \mathrm{~V}$ to $2 \mathrm{~V}$ increase in voltage, with an efficiency increment of $1 \%$ to $1.27 \%$. The test results of USP37 show the voltage increase of $1.2 \mathrm{~V}$ to $2.1 \mathrm{~V}$ in the PV module voltage. Due to the increase in voltage, efficiency increment of $1.29 \%$ is observed. The efficiency of USP36 with water spraying is more than the efficiency of USP37 without water spraying. In the $\mathrm{PV}$ power systems, an average increase in efficiency of $0.5 \%$ is observed.

\section{Introduction}

The operation of a water pumping system needs a power source. Overall, when an AC power supply is available from the nearby power grid, the AC power system is economical and requires minimum maintenance. However, water sources are spread over many miles of land in rural areas, and power lines are scarce. It is also prohibitively costly to install a modern transmission line and a transformer at the site. In such places, windmills have historically been installed; however, many of them are now inactive due to inadequate maintenance and aging. Most stand-alone water pumping systems today use internal combustion engines. There are compact and easy to mount programs. However, they do have some big drawbacks, such as they need regular refueling and repair site visits, and in addition, diesel fuel is often costly and not readily accessible in rural areas of many developed countries. Fossil fuel consumption also has an environmental effect, particularly the carbon dioxide $\left(\mathrm{CO}_{2}\right)$ release into the atmosphere. By implementing clean energy systems, which are now cost-competitive with fossil fuels in some instances, $\mathrm{CO}_{2}$ emissions can be significantly reduced. Carbon dioxide emissions in 2010 and 2020, by select country (in million metric tons), is shown in Figure 1. A very attractive idea is the use of green energies for water pumping systems. In particular, for applications needing less than $10 \mathrm{~kW}$, where grid energy is not possible, and where internal combustion engines are costly to run, PV systems are incredibly efficient and are mostly preferred because they provide the lowest cost of the life cycle. PV is a desirable economic option if the water supply is $1 / 3$ mile or more away from the power line [1]. 


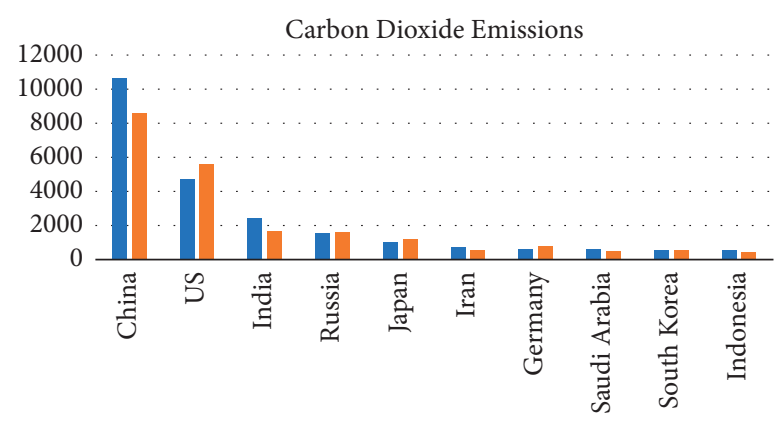

- 2020

- 2010

FIgUre 1: Global $\mathrm{CO}_{2}$ emissions in 2010-2020.

The removal of heat from the front surface into the water spray over the cells that absorb the heat produced by the cells during the day will minimize the loss of productivity due to the increased temperature of PV arrays. Spraying water over the cells has been shown to increase the average performance of PV cells, subsystem efficiency, and overall efficiency by $3.26 \%, 1.40 \%$ and $1.35 \%$, respectively. The overall productivity of PV cells in normal conditions is $13.5 \%$. Measurements of the modules' short circuit current, almost independent of temperature, showed that the water spray increased the optical output by $1.8 \%$. Reducing the temperature of the cell and lack of reflection will also decrease the threshold radiation during the hot days of the starting motor pump torque and contributes to an increase in the early morning consumer requirement $[2,3]$.

\section{Literature Work}

The operation of a separately excited, series, and shunt motor is investigated and concluded that a separately excited motor coupled to a centrifugal pump was the most suitable for a solar cell generator. They conclude that after comparison, the DC motor has the advantage of higher utilization of PV power, and direct coupling between the DC motor and the PV generator reduces the cost of the system [4-7].

Jafar [8] suggested a very simple but precise method to model the PV water pumping system, which, given the head and irradiance, is applied to the solar star 1000 pumping system to arrive at a model that calculates the volume flow rate. When used to power water pumps, PV does not need any storage batteries, which means significant cost savings and contributes to a device that is efficient and needs less maintenance $[9,10]$.

Langridge et al. [11] indicated that an improvement in overall system performance would decrease the size of the PV array and hence the expense of the capital system, which is largely driven by the cost of the PV array. A PV pumping system using a DC brushless motor has been developed. This paper outlines the system's operation and the creation of array part models and the brushless DC engine. Simulation results are included as well as subsequent test results for the entire system. Through a variety of loads and working conditions for $4 \times 1$ and $4 \times 2$ array setups, efficiencies of between 30 and 50 percent for the system (excluding the array) have been obtained [12-14].

This method only uses the knowledge available from the suppliers of the PV module and pump motor. From monthly averages of horizontal radiation and ambient temperatures, the weather data is "generated" using well-known weather data statistics. Based on hourly weather info, the system forecasts the monthly pumped water within 6 percent of TRNSYS predictions. The use of a single average monthly day has been seen to forecast monthly pumped water at low average monthly radiation levels and to predict monthly pumped water at moderate radiation levels and above. The use of a single monthly average day provides a fair calculation of monthly pumped water only at high radiation levels $[15,16]$.

A method of the electrical yield through water flow over the front of PV panels is suggested. Numerous ideas have been suggested to minimize reflection. Still, most of them have drawbacks such as the anti-reflective coatings are not durable, and structured surfaces are pricey, dust collection, and are hard to clean. In addition to helping to maintain clear surface, water reduces reflection by 2-3.6 percent, reduces cell temperatures by up to $22^{\circ} \mathrm{C}$, and can return a 10.3 percent surplus; even after accounting for the electricity required to operate the pump, a net benefit of 8-9 percent can be obtained $[17,18]$.

A. Moussi. et al. [19] with enhanced performance, a permanent magnet brushless DC motor PV pumping system was developed. According to this proposal, where insolation differs far from the nominal value and where the machine was sized, the efficiency of a photovoltaic pumping system based on an induction engine is degraded. The findings of the simulation indicate that the suggested solution achieves an improvement in both the regular pump quantity and pump efficiency. The generator voltage control law, however, leads to a less costly and non-complex application. The arrangement of MPPT control does not always lead to maximum efficiency of the system. For optimum usage of PV water pumping systems, proper sizing of system components is important [20]. Combining a battery bank and a water tank is the most cost-effective way to address the irrigation difficulties that arise during dry weather. The 
PVWPS is yet to be explored in locations of the Arctic where solar radiation is very high at certain times of the year. Weather conditions, high atmospheric transparency, clean air, and radiation reflection from ice and ice may all help the photoelectric modules work more efficiently. These locations, however, are sparsely populated and hard to reach [21-23].

This literature study helps to understand the problems in the performance of photovoltaic cells and solutions to increase the performance. It is incurred from the study that at increased temperatures, i.e., beyond $45^{\circ} \mathrm{C}$, the power output from the PV cells decreases. This is due to the basic characteristic of PV cells. The loss of power is reduced by reducing the PV cell temperature. Water spraying over the cells will reduce the temperature and helps to increase power and efficiency.

\section{Methodology}

Loss of efficiency due to a raised temperature of PV cells can be reduced by heat removal from the PV cell front surface by spraying water over the cells, which absorbs the heat from the cells. The temperature of the PV cell is measured using the LM35 temperature sensor, and the output is fed into the control unit. The control unit includes a microcontroller that compares the measured temperature with the reference temperature and controls the MOSFET switch.

If the measured temperature is more than the reference temperature, then the microcontroller produces the pulse width modulation (PWM) signal to trigger the MOSFET. The MOSFET acts as a switch between the solenoid valve and the power supply. A solenoid valve is placed between the water tank and the spraying unit. Water spraying includes flexible PVC tubes with appropriate holes for water flow. The change in voltage before and after spraying water is measured using a voltage sensor and is displayed in the LCD. The temperature variation is also displayed in LCD (Figure 2).

\section{Experimental Setup}

This chapter deals with the experimental setup of the project work, including the temperature measurement, control unit, and water spraying unit.

The circuit of the control system is shown in Figure 3. The LCD is interfaced with the microcontroller to display the measured temperature and voltage. A PIC microcontroller is provided with the reset circuit, which includes two Schmitt triggers 7414. A $12 \mathrm{MHz}$ crystal oscillator is connected to the PIC microcontroller. A Darlington amplifier configuration using two BC547 transistors is used to amplify the PWM signals from the microcontroller. The IRF250 MOSFET is connected between the solenoid valve and the power supply.

Figure 4 depicts the basic components of a solenoid valve. The valve shown in the picture is a normally-closed direct-acting valve. This type of solenoid valve has the simplest and easy-to-understand principle of operation. The media controlled by the solenoid valve enters the valve through the inlet port. The media must flow through the orifice before continuing into the outlet port. The orifice is closed and opened by the plunger.

The valve pictured above is a normally-closed solenoid valve. Normally closed valves use a spring that presses the plunger tip against the opening of the orifice. The sealing material at the tip of the plunger keeps the media from entering the orifice until the plunger is lifted up by an electromagnetic field created by the coil.

The LM35 temperature sensor is fixed on the backside of the PV module. It is kept back to prevent the sensor from getting wet due to the water sprayed over the cells. The temperature at the backside of $\mathrm{PV}$ cell is $2^{\circ} \mathrm{C}$ more as compared to that of the front side of the cell. The control unit includes a voltage sensor, MOSFET switch control, and LCD. The output voltage from a single PV module is given to the voltage sensor for measurement and display. PIC16F877 microcontroller controls the MOSFET switch according to the output from the temperature sensor. The MOSFET switch is connected between the $12 \mathrm{~V}$ power supply and solenoid valve.

Figure 5 shows the water spraying unit of the experimental setup in which solenoid valve and flexible tubes of $5 \mathrm{~mm}$ diameter are included. Uniform holes at equal distances in the tubes are made for water flow. LM35 measures the temperature and the output is fed to the microcontroller. The microcontroller compares the measured temperature with a reference value. If the measured temperature value is greater than the reference value, then the microcontroller produces a PWM signal, and the MOSFET gets energized. If the MOSFET switch is closed, a $12 \mathrm{~V}$ supply is applied across the solenoid valve. Energizing the solenoid opens the valve, and thereby water flows over the cells, which is shown in Figure 6. The sun's radiation is measured using the pyranometer, and the temperature of the PV cell is measured by an IR thermometer while the experiment is conducted manually. Then the temperature is measured using an LM35 temperature sensor, and the water spraying is performed automatically by the controller unit.

\section{Results and Discussion}

This section deals with the results of experiments conducted in various PV modules and its discussion. In this paper, experiments are conducted with different PV modules at various temperature ranges. USP36, USP37, a flexible panel, and USP10 are the PV modules with which experiments are conducted at different periods. Various parameters, including voltage, current, temperature, time, and solar radiation, are measured during the experimentation. The experiment is conducted with and without water spraying over the cells.

5.1. Experimental Results of USP36 PV Module. A single USP36 PV module is used for experimentation. This PV module has already completed a lifetime of 10 years. It is tested with and without water spraying throughout the day at regular time intervals. A $16 \Omega$ resistive heating element is used as a load for this experiment. 


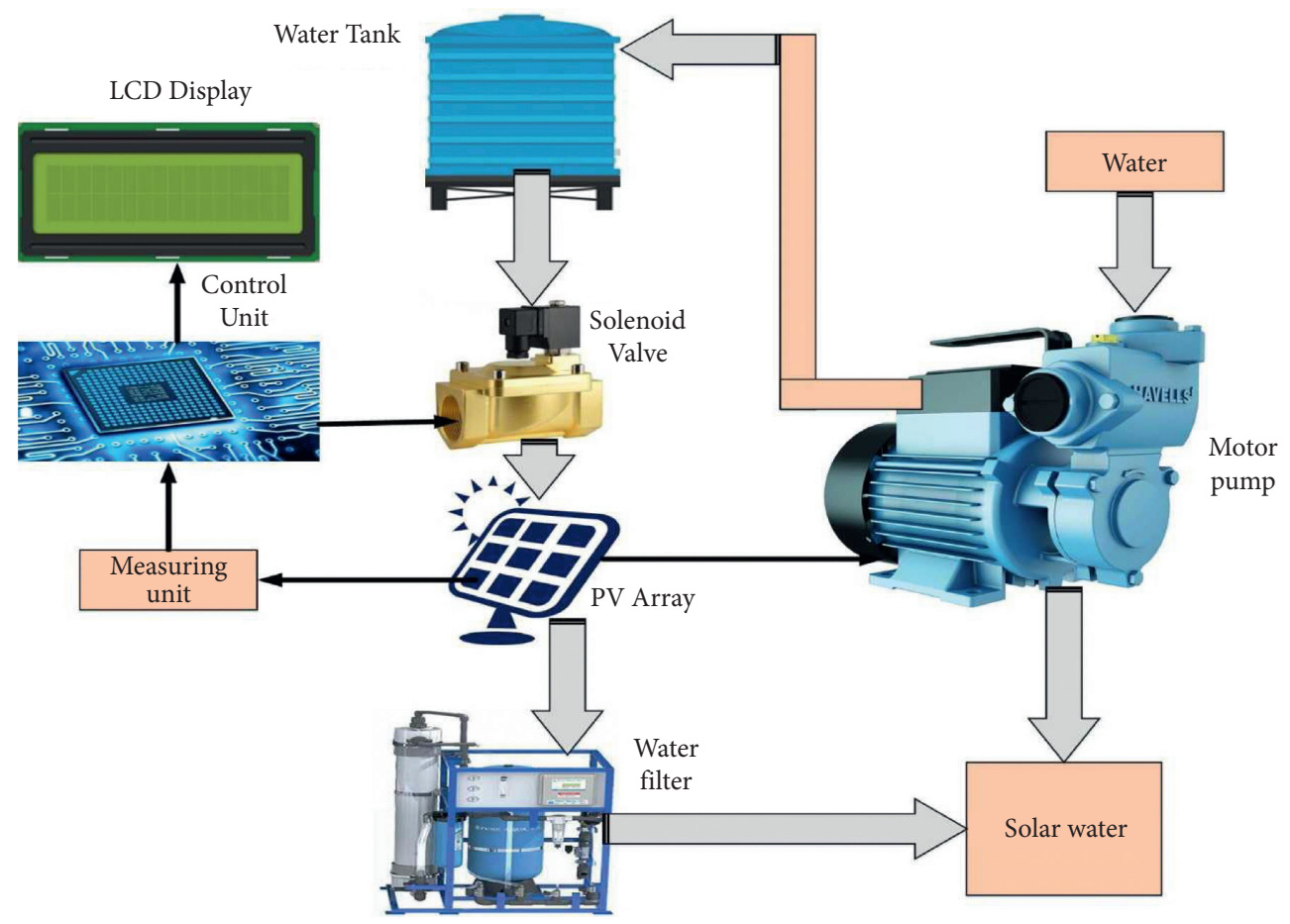

Figure 2: Proposed block diagram.

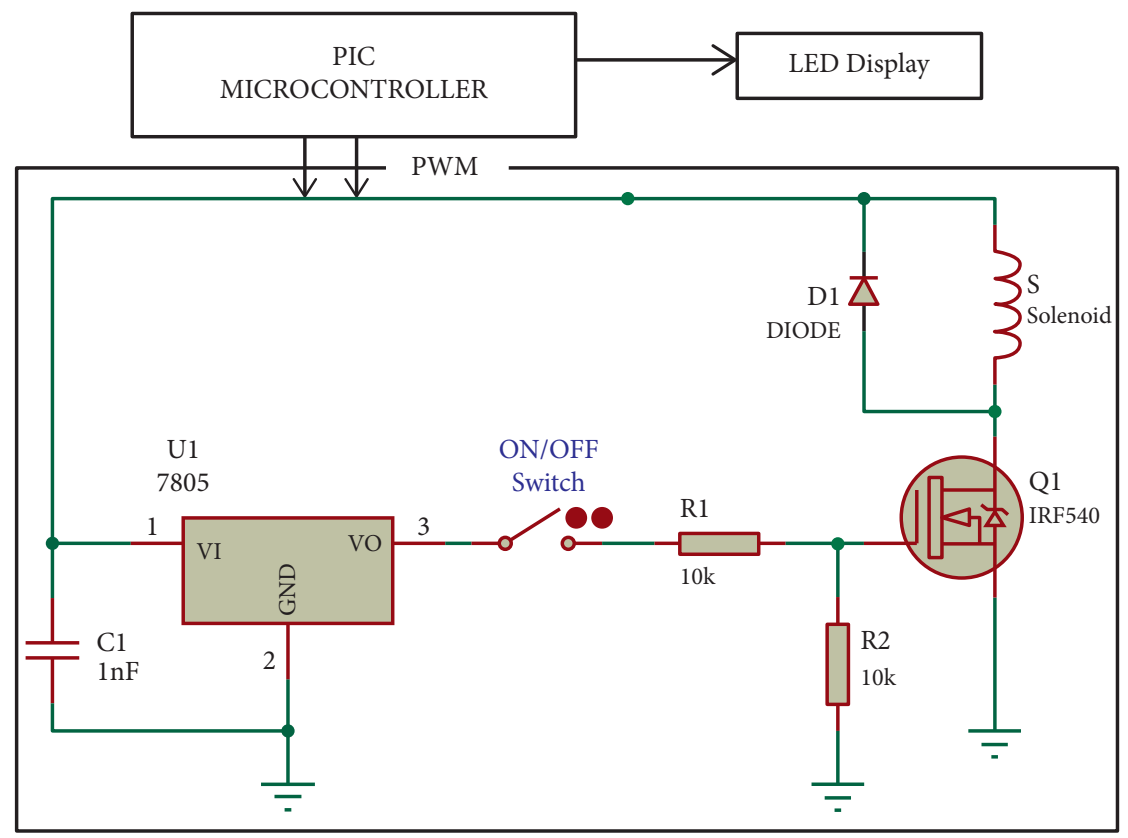

Figure 3: Control circuit.

The experiment was conducted on a $36 \mathrm{~W}$ PV panel. From the results, it is clear that the voltage and current values after water spraying vary with respect to solar radiation. It shows that from $12.00 \mathrm{pm}$ to $01.00 \mathrm{pm}$, the cell temperature is $50^{\circ} \mathrm{C}$ to $60^{\circ} \mathrm{C}$, at which the voltage drops. There is a gradual increase in voltage from 8 am to $12.00 \mathrm{pm}$, after then the voltage drops due to increased cell temperature. After $01.00 \mathrm{pm}$ again, the voltage increases gradually and decreases towards evening with respect to solar radiation. The voltage increases with the increase in solar radiation unless the temperature exceeds $45^{\circ} \mathrm{C}$. The current increases gradually with a rise in solar radiation, and there are small changes with the increase in temperature, which is negligible when compared with the voltage variation. At increased temperature, spraying water over the cells increases the cell voltage, and the current decreases slightly. 


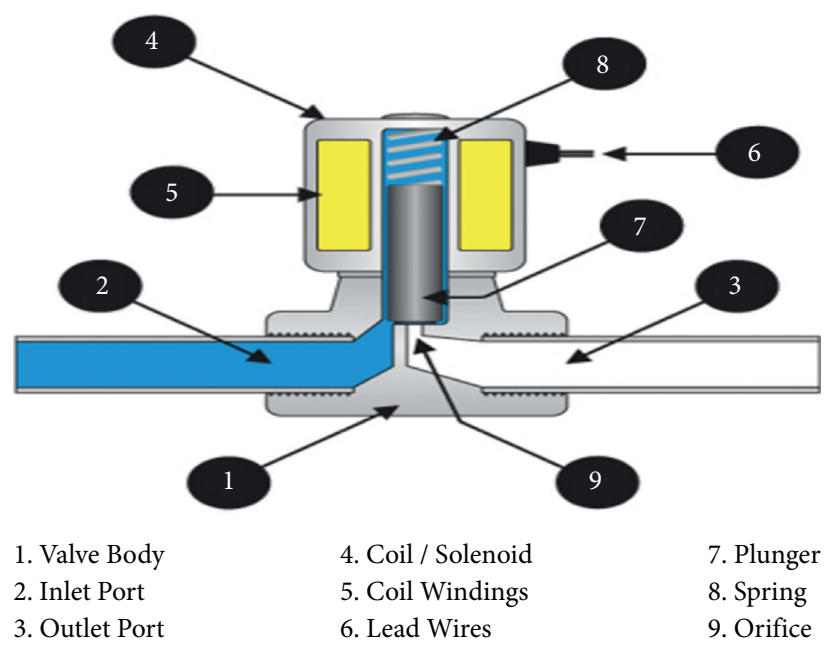

Figure 4: Solenoid valve.

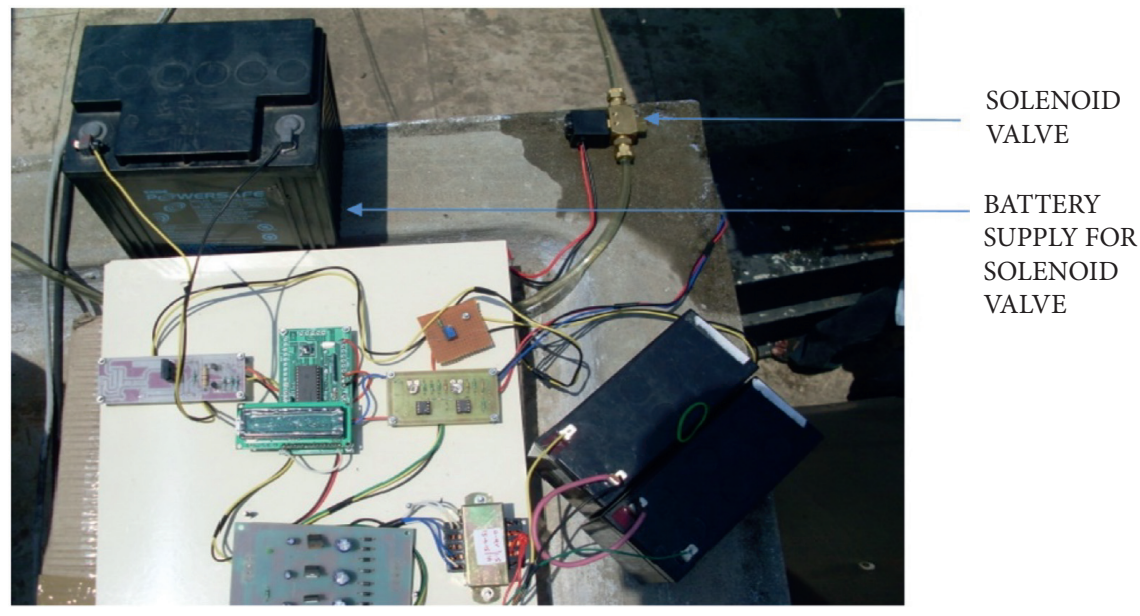

Figure 5: Experimental setup.

The increase in voltage is significantly more, while a decrease in the current is very small. Voltage increment is in the range of $1.5 \mathrm{~V}$ to $2.0 \mathrm{~V}$ approximately, and the current variation is in the range of $0.01 \mathrm{~A}$ to $0.03 \mathrm{~A}$.

The tabulated experimental results are plotted in the graph, and the variations are compared. Figure 7 shows the voltage output from the PV panel with and without spraying water over the cells. On comparing the voltage output with and without spraying water, it is found that an average of $1 \mathrm{~V}$ is increased by spraying water.

The current output from the panel with and without water spraying is shown in Figure 8. Though current is dependent on the temperature, there is a small increase in the valve on reducing temperature.

The power output from the PV module before and after spraying water is shown in Figure 9. A maximum of $4 \mathrm{~W}$ increase in power is found at $12.30 \mathrm{pm}$ after spraying water. Figure 10 shows the comparison of the efficiency of the PV module with and without water spraying. It shows that there is an average increase of $1 \%$ efficiency with a maximum increase of $1.5 \%$ efficiency after spraying water.
Figure 11 shows the comparison of PV cell temperature before and after spraying water. On comparing, a maximum of around $20^{\circ} \mathrm{C}$ temperature decrease is found. An average of around $10^{\circ} \mathrm{C}$ temperature decrease is obtained.

5.2. Experimental Results of USP37 PV Module. A newly bought USP37 PV module has been experimented with this project to compare the output with that of the old USP36 PV module. It is tested with and without water spraying throughout the day at regular time intervals. A $16 \Omega$ resistive heating element is used as a load for this experiment.

The experiment was conducted on a $37 \mathrm{~W}$ PV panel. From the results, it is clear that the voltage and current values after water spraying vary with respect to solar radiation. There is a gradual increase in voltage from 8 am to $12.00 \mathrm{pm}$; after then, the voltage drops due to increased cell temperature. After $01.00 \mathrm{pm}$, again the voltage increases gradually and decreases towards evening with respect to solar radiation. It shows that from $12.00 \mathrm{pm}$ to $01.00 \mathrm{pm}$, the cell temperature is $50^{\circ} \mathrm{C}$ to $60^{\circ} \mathrm{C}$, at which the voltage drops. 


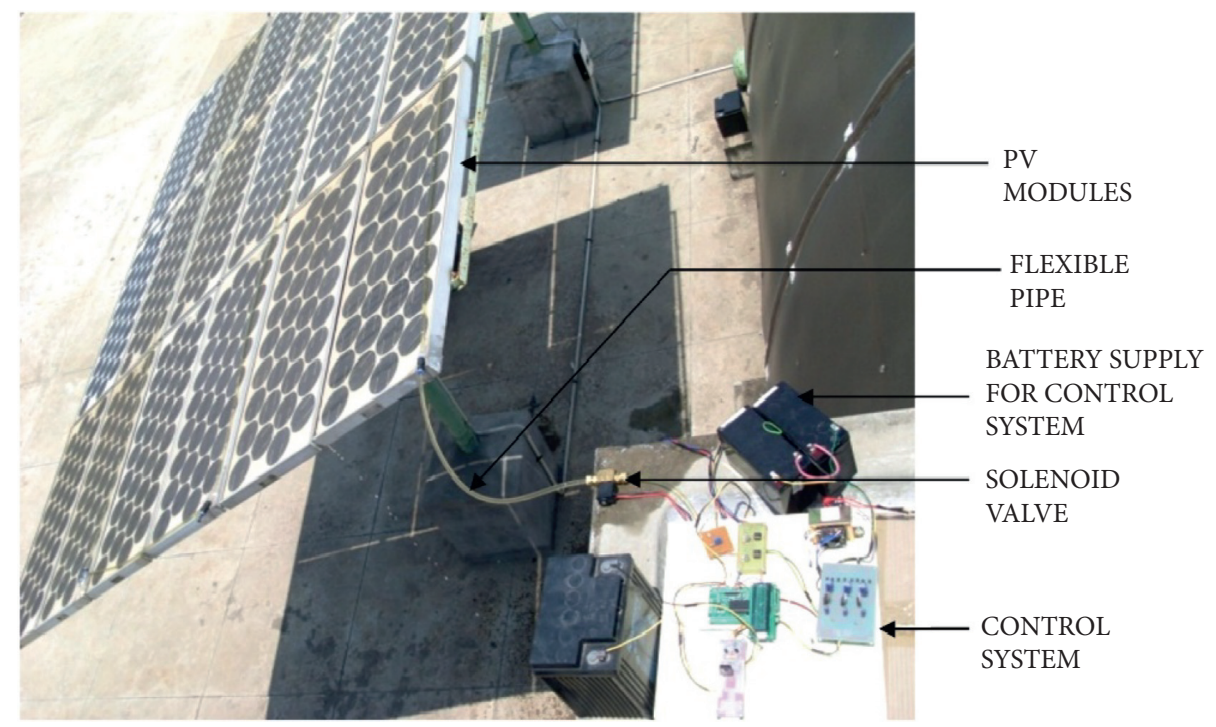

FIGURE 6: Water spraying setup.

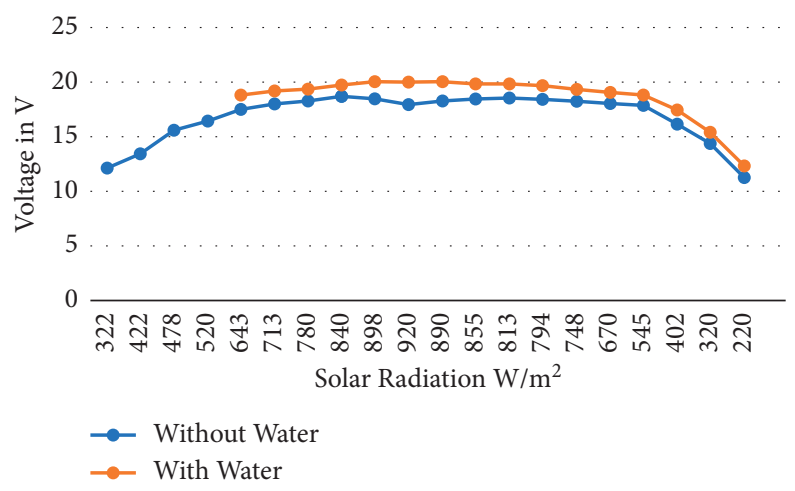

FIGURE 7: Voltage comparison of USP36 with and without water spray.

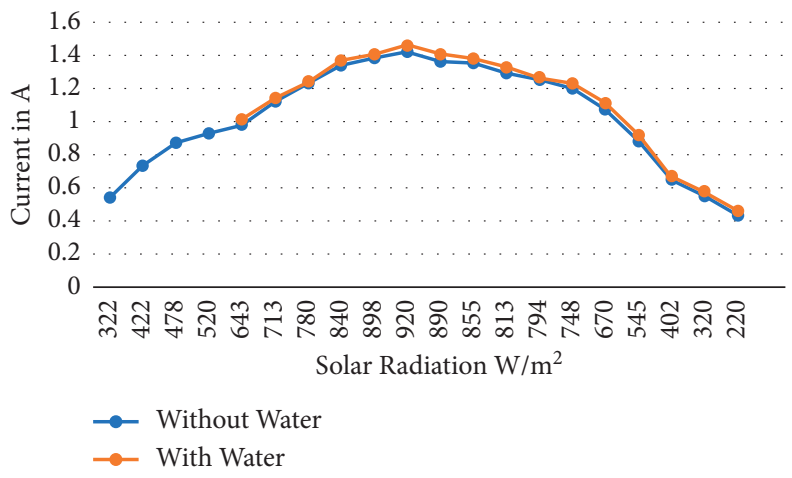

FIGURE 8: Current comparison of USP36 with and without water spray.

The voltage increases with the increase in solar radiation unless the temperature exceeds a certain limit. The current increases gradually with the rise in solar radiation, and there are small changes with the increase in temperature. At increased temperature, spraying water over the cells increases the cell voltage, and the current decreases slightly. The increase in voltage is significantly more, while a decrease in the current is very small.

The tabulated experimental results are plotted in the graph, and the variations are compared. Figure 12 shows the voltage output from the PV panel with and without spraying water over the cells. On comparing the voltage output with 


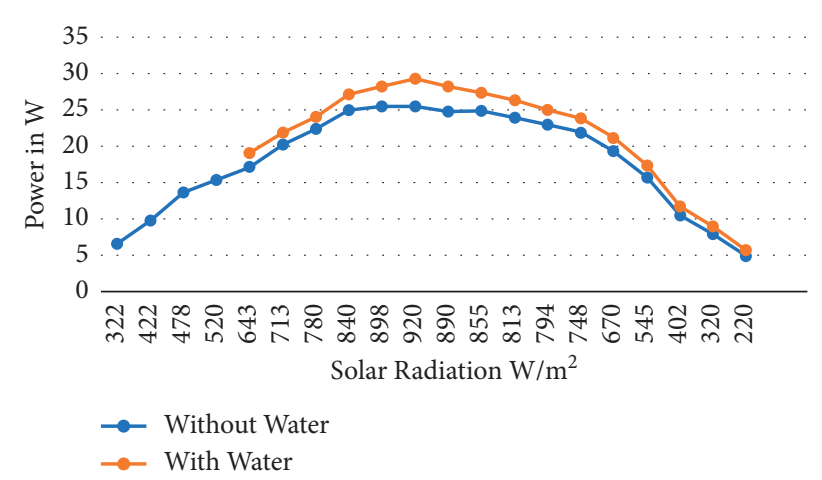

FIGURE 9: Power comparison of USP36 with and without water spray.

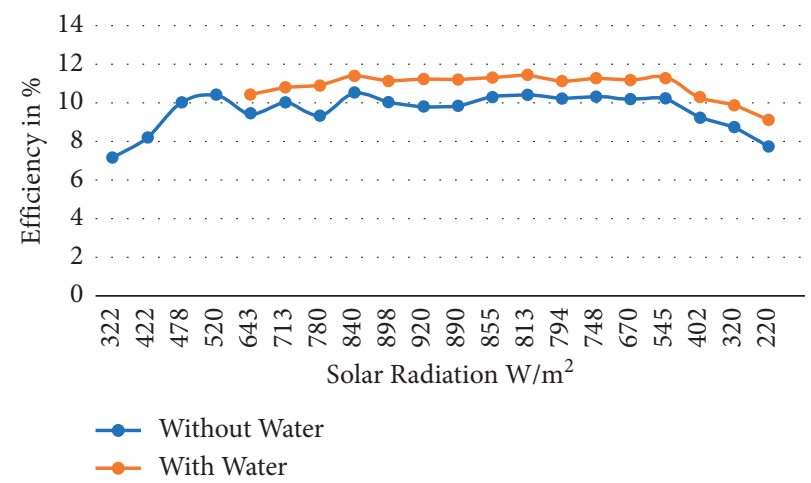

FIGURE 10: Efficiency comparison of USP36 with and without water spray.

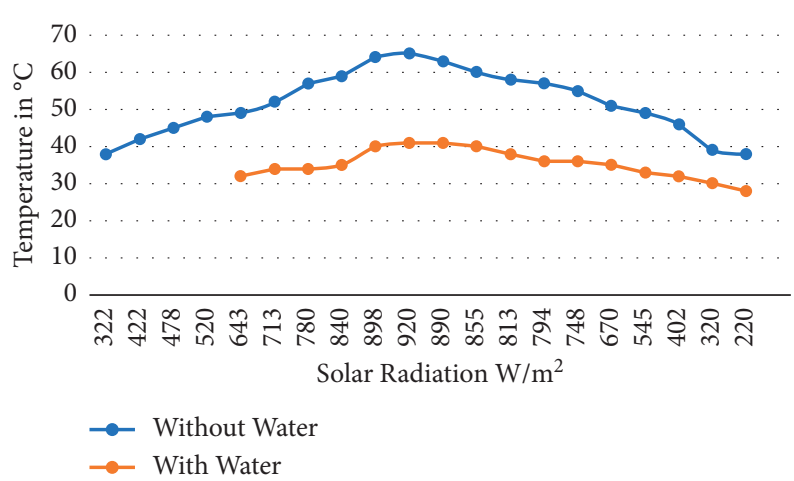

FIGURE 11: Comparison of the temperature of USP36 with and without water spray.

and without spraying water, it is found that an average of $1 \mathrm{~V}$ is increased by spraying water.

The current output from the panel with and without water spraying is shown in Figure 13. Though the current is dependent on the temperature, there is a small increase in the valve on reducing temperature.

The power output from the PV module before and after spraying water is shown in Figure 14. A maximum of $4 \mathrm{~W}$ increase in power is found at $12.30 \mathrm{pm}$ after spraying water. Figure 15 shows the comparison of the efficiency of the PV module with and without water spraying. It shows that there is an average increase of $1 \%$ efficiency with a maximum increase of $1.5 \%$ efficiency after spraying water.

Figure 16 shows the comparison of the PV cell temperature before and after spraying water. On comparing, a maximum of around $20^{\circ} \mathrm{C}$ temperature decrease is found. An average of around $10^{\circ} \mathrm{C}$ temperature decrease is obtained.

Figure 17 shows the comparison of efficiencies of USP36 and USP37 PV modules with and without water spraying. It is clear from the graph that the efficiency of the USP36 PV module with water spraying is more than the efficiency of the USP37 PV module without water spraying. 


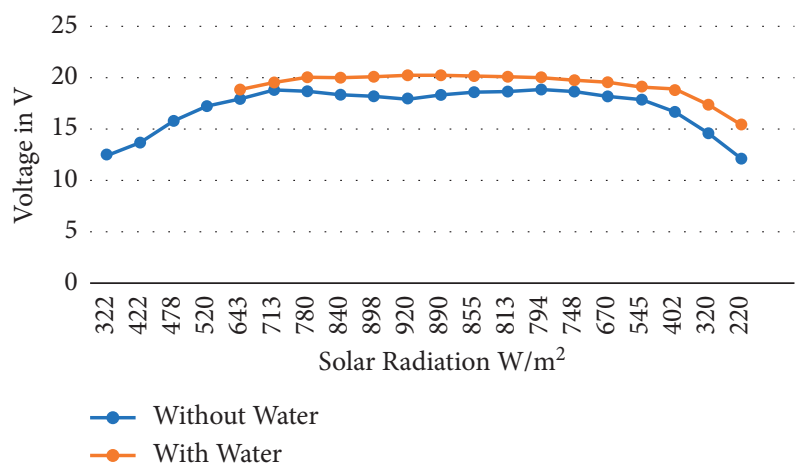

FIGURE 12: Voltage comparison of USP37 with and without water spray.

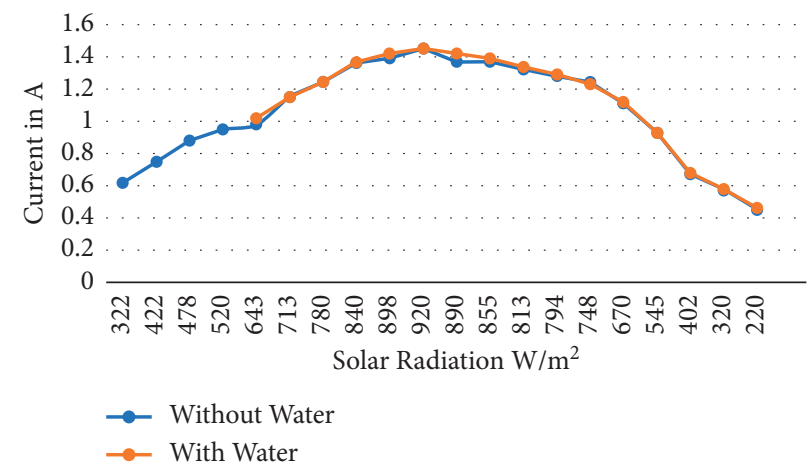

FIGURE 13: Current comparison of USP37 with and without water spray.

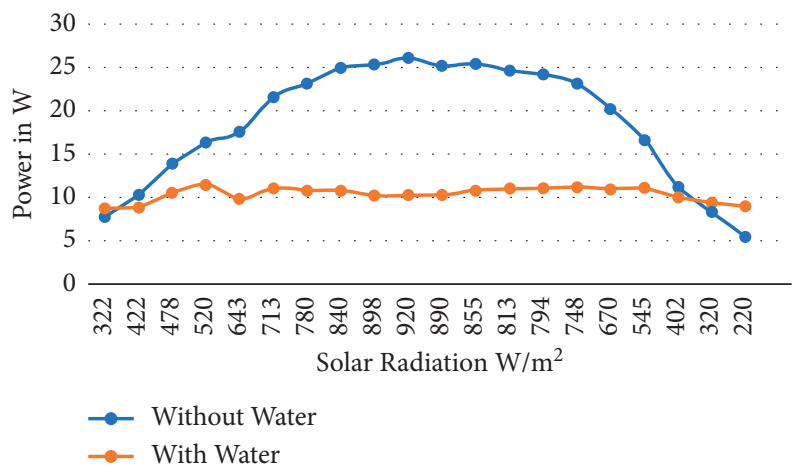

FIgURE 14: Power comparison of USP37 with and without water spray.

5.3. Experimental Results of PV System. The experiment is conducted on a PV system with 26 USP36 PV modules. A 1 HP DC motor is connected as a load which drives the centrifugal pump to pump up the water. The tabulated experimental results are plotted in the graph, and the variations are compared. Figure 18 shows the voltage output from the PV system with and without spraying water over the cells. On comparing the voltage output with and without pouring water, it is found that an average of $0.8 \mathrm{~V}$ is increased by rushing water.

The current output from the PV system with and without water spraying is shown in Figure 19. Though the current is dependent on the temperature, there is a small increase in the valve on reducing temperature.

The power output from the PV system before and after spraying water is shown in Figure 20. A maximum of $34 \mathrm{~W}$ increase in power is found at $12.30 \mathrm{pm}$ after spraying water. Figure 21 shows the comparison of the efficiency of the PV system with and without water spraying. It shows that there is an average increase of $0.5 \%$ efficiency with a maximum increase of $1.0 \%$ efficiency after spraying water. 


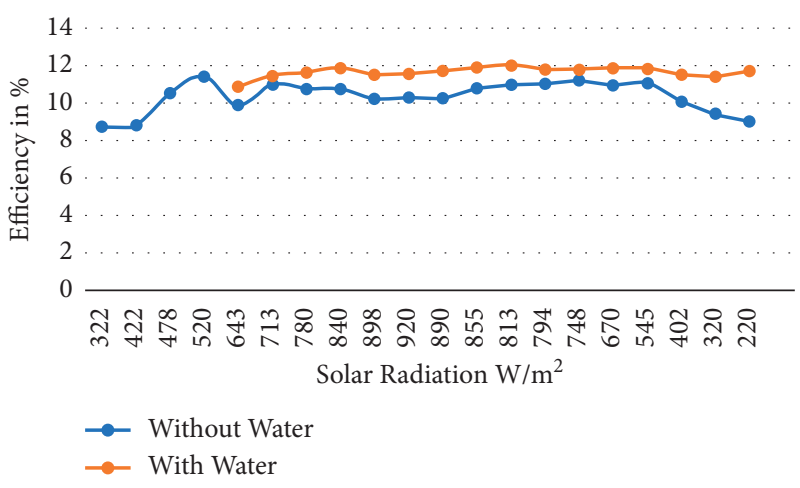

FIGURE 15: Efficiency comparison of USP37 with and without water spray.

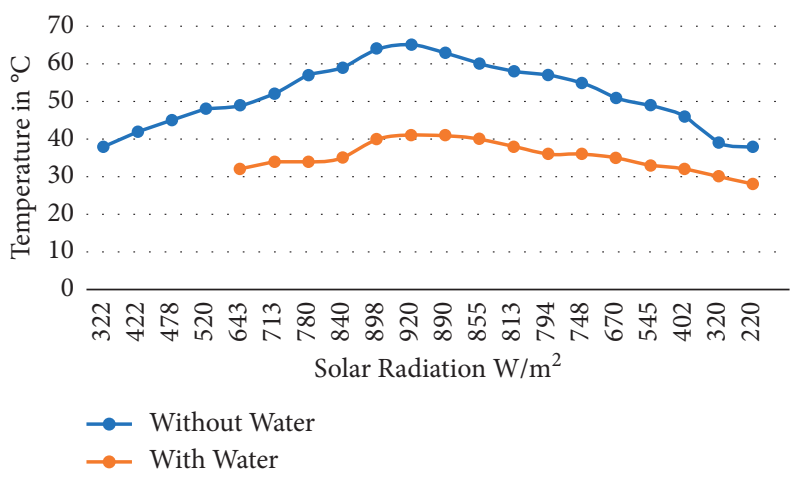

FIgURE 16: Temperature comparison of USP37 with and without water spray.

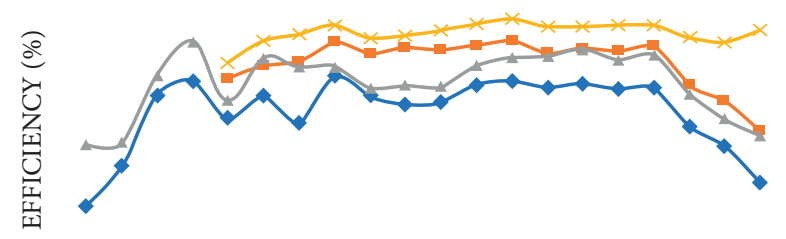

SOLAR RADIATION $\left(\mathrm{W} / \mathrm{m}^{2}\right)$

$\leadsto$ efficiency of usp 36 WITHOUT WATER

$\because-$ efficiency of usp 36 WITH WATER

$\simeq$ efficiency of usp 37 WITHOUT WATER

FIGURE 17: Comparison of efficiencies of USP36 and USP37 with and without water spraying.

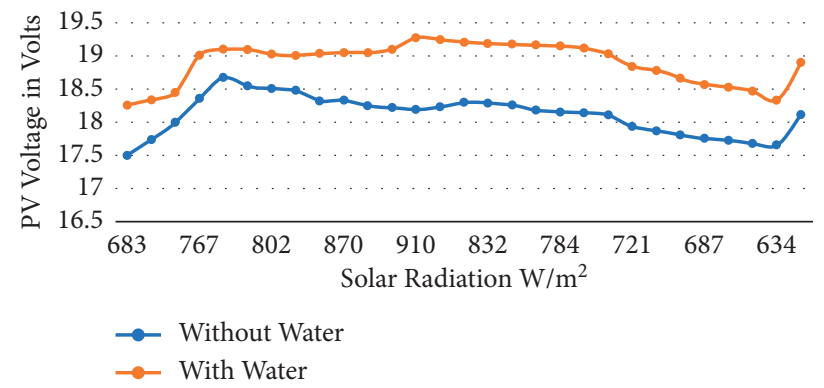

Figure 18: Voltage comparison of PV system with and without water spray. 


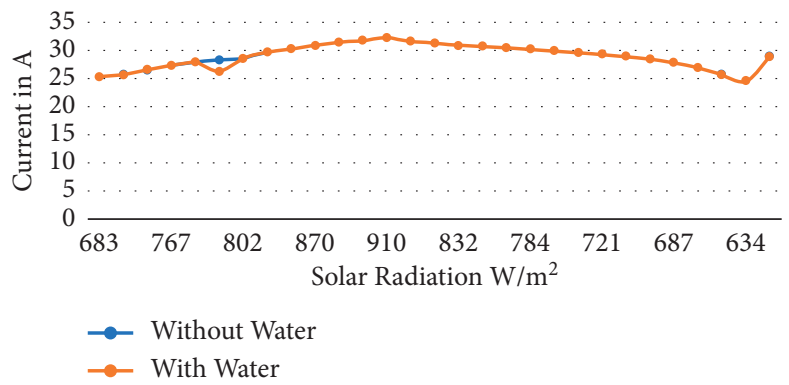

Figure 19: Current comparison of PV system with and without water spray.

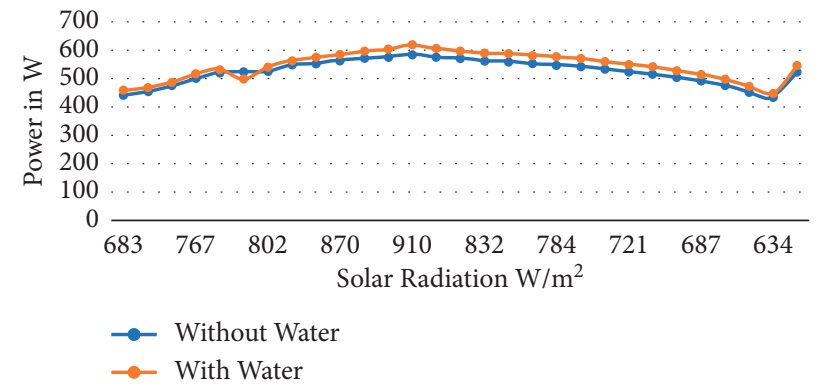

FIgURE 20: Power comparison of PV system with and without water spray.

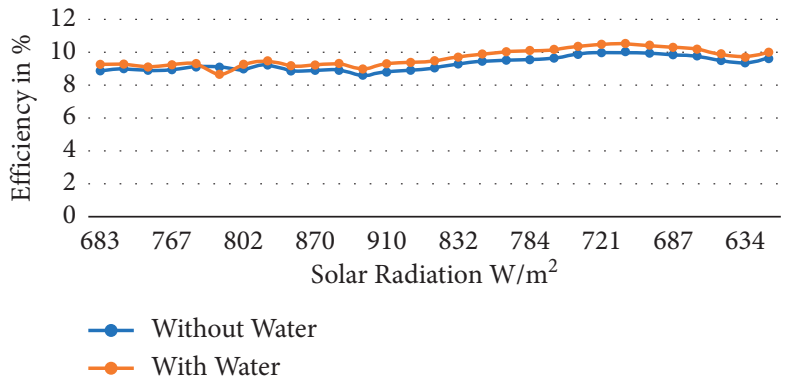

FIGURE 21: Efficiency comparison of PV system with and without water spray.

\section{Conclusion}

In this research, loss of efficiency due to the temperature rise in PV arrays is reduced by spraying water over the cells. The efficiency of the USP36 PV module with water spraying is more than the efficiency of the USP37 PV module without water spraying. It is found that spraying water over the photovoltaic cells enormously improves the PV system efficiency by around $0.5 \%$. Thus the efficiency increase in the PV system increases the water pumping system efficiency. The approximate calculation reveals that 15.6 liters/day of water is sprayed over the entire PV modules at temperatures beyond $45^{\circ} \mathrm{C}$. Due to this, water gets heated, and its temperature rises to an average of $30^{\circ} \mathrm{C}$. The water with increased temperature is fed into the solar water heating system, which improves the water heating system performance. In the future, the proposed methodology can be used for the domestic PV power system with an integrated water heating system.

\section{Data Availability}

The data used to support the findings of this study are available from the corresponding author upon request.

\section{Conflicts of Interest}

The authors declare that they have no conflicts of interest.

\section{References}

[1] D. H. Muhsen, T. Khatib, and H. T. Haider, "A feasibility and load sensitivity analysis of photovoltaic water pumping system with battery and diesel generator," Energy Conversion and Management, vol. 148, pp. 287-304, 2017.

[2] R. Rawat, S. C. Kaushik, and R. Lamba, "A review on modeling, design methodology and size optimization of photovoltaic based water pumping, standalone and grid connected system," Renewable and Sustainable Energy Reviews, vol. 57, pp. 1506-1519, 2016. 
[3] Y. Imene, A. Ahmad, A. Sernac, and F. Tadeoc, "Sensitivity analysis for photovoltaic water pumping systems: energetic and economic studies," Energy Conversion and Management, vol. 135, pp. 402-415, 2017.

[4] A. M. Zaki and M. N. Eskander, "Matching of photovolatic motor-pump systems for maximum efficiency operation," Renewable Energy, vol. 7, no. 3, pp. 279-288, 1996.

[5] W. H. Kazeza, S. P. Chowdhury, and L. J. Ngoma, "Optimization of a solar based water pumping system using a high step up inverter," in Proceedings of the International Conference on Renewable Power Generation (RPG 2015), pp. 1-6, Beijing, China, October 2015.

[6] G. Biji, "Modelling and simulation of PV based pumping system for maximum efficiency," in Proceedings of the 2012 International Conference on Power, Signals, Controls and Computation, pp. 1-6, Thrissur, India, January 2012.

[7] A. Moussi and A. Torki, "An improved efficiency Permanent Magnet brushless DC motor PV pumping system," LARHYSS 144 Journal, vol. 1, 2002.

[8] M. Jafar, "A model for small-scale photovoltaic solar water pumping," Renewable Energy, vol. 19, no. 1-2, pp. 85-90, 2000.

[9] S. M. A. Ibrahim, H. H. El-Ghetany, and A. G. M. Shabak, "Comprehensive design tool for sizing solar water pumping system in Egypt," Applied Solar Energy, vol. 56, no. 1, pp. 18-29, 2020.

[10] A. Al-Badi, H. Yousef, T. Al Mahmoudi, M. Al-Shammaki, A. Al-Abri, and A. Al-Hinai, "Sizing and modelling of photovoltaic water pumping system," International Journal of Sustainable Energy, vol. 37, no. 5, pp. 415-427, 2017.

[11] D. Langridge, W. Lawrance, and B. Wichert, "Development of a photo-voltaic pumping system using a brushless d.c. motor and helical rotor pump," Solar Energy, vol. 56, no. 2, pp. 151-160, 1996.

[12] R. Nisha and K. G. Sheela, "Review of pv fed water pumping systems using BLDC motor," Materials Today Proceedings, vol. 24, no. 3, pp. 1874-1881, 2020.

[13] R. Kumar and B. Singh, "BLDC motor driven water pump fed by solar photovoltaic array using boost converter," in Proceedings of the 2015 Annual IEEE India Conference (INDICON), pp. 1-6, New Delhi, India, December 2015.

[14] B. Singh and R. Kumar, "A simple BLDC motor drive for solar PV array fed water pumping system," IET Power Electronics, vol. 9, no. 7, 2016.

[15] B. Singh, U. Sharma, and S. Kumar, "Standalone photovoltaic water pumping system using induction motor drive with reduced sensors," IEEE Transactions on Industry Applications, vol. 54, no. 4, 2018.

[16] R. Chinthamalla, S. Padmanaban, R. Karampuri, S. Jain, A. H. Ertas, and V. Fedak, "A solar PV water pumping solution using a three-level cascaded inverter connected induction motor drive," Engineering Science and Technology, an International Journal, vol. 19, no. 4, pp. 1731-1741, 2016.

[17] P. Choudhary, R. K. Srivastava, and S. De, "Solar powered induction motor-based water pumping system: a review of components, parameters and control methodologies," in Proceedings of the Conference: 2017 4th IEEE Uttar Pradesh Section International conference on Electrical, Computer and Electronics (UPCON), Mathura, India, October 2017.

[18] P. Dwivedi, K. Sudhakar, A. Soni, E. Solomin, and I. Kirpichnikova, "Advanced cooling techniques of PV modules: a state of art," Case Studies in Thermal Engineering, vol. 21, Article ID 100674, 2020.
[19] K. Benlarbi, L. Mokrani, and M. S. Nait-Said, “A fuzzy global efficiency optimization of a photovoltaic water pumping system," Solar Energy, vol. 77, no. 2, pp. 203-216, 2004.

[20] A. Betka and A. Moussi, "Performance optimization of a photovoltaic induction motor pumping system," Renewable Energy, vol. 29, no. 14, pp. 2167-2181, 2004.

[21] S. Biswas and M. T. Iqbal, "Dynamic modelling of a solar water pumping system with energy storage," Journal of Solar Energy, vol. 2018, Article ID 8471715, 12 pages, 2018.

[22] O. V. Shepovalova, A. T. Belenov, and S. V. Chirkov, "Review of photovoltaic water pumping system research," Energy Reports, vol. 6, no. S6, pp. 306-324, 2020.

[23] M. Das and R. Mandal, "A comparative performance analysis of direct, with battery, supercapacitor, and battery-supercapacitor enabled photovoltaic water pumping systems using centrifugal pump," Solar Energy, vol. 171, pp. 302-309, 2018. 